\title{
Temperature-driven biogeography of the deep-sea family Lithodidae (Crustacea: Decapoda: Anomura) in the Southern Ocean
}

\author{
Sally Hall $\cdot$ Sven Thatje
}

Received: 5 May 2010 / Revised: 29 July 2010 / Accepted: 21 September 2010 / Published online: 15 October 2010

(C) Springer-Verlag 2010

\begin{abstract}
Species' distributions are dynamic and are linked to the changing physical environment. Temperature is considered to be a major factor influencing biogeography, especially in ectotherms such as the family Lithodidae. Lithodids are rare amongst decapods in their ability to inhabit the higher latitudes of the Southern Ocean; however, they are usually found in locations where water temperature is above $0.5^{\circ} \mathrm{C}$. This study, for the first time, provides a baseline indication of the limits of the lithodid distribution around Antarctica, which will be instrumental in any future work on range extensions in this group. The distribution of lithodids is likely to change as temperatures along the West Antarctic Peninsula continue to rise, and range extensions by durophagous predators, such as the lithodids, are regarded as a potential threat to the unique structure of Antarctic continental-shelf ecosystems.
\end{abstract}

Keywords Cold adaptation · King crab · Predators · Climate change $\cdot$ Polar ecosystems $\cdot$ Biogeography

\section{Introduction}

Lithodid crabs are a group of predominantly deep-sea crustaceans, whose predatory trophic position and commercial fishery makes their dynamic global distribution interesting. The family Lithodidae occupies predominantly cold-water habitats (Zaklan 2002; Thatje and Arntz 2004; Hall and

S. Hall $(\bowtie) \cdot$ S. Thatje

National Oceanography Centre, Southampton,

School of Ocean and Earth Science, University of Southampton,

European Way, Southampton SO14 3ZH, UK

e-mail:smh57@noc.soton.ac.uk
Thatje 2009) and temperature is a constraining factor for distribution, particularly because of its effect on early life-history stages (Anger et al. 2003; Thatje et al. 2005). Lineage-wide lower and upper thermal limits have been predicted (approximately 0.5 and $15^{\circ} \mathrm{C}$ respectively) for deep-sea genera of the Lithodidae (Lithodes, Paralomis, Neolithodes) and their secondarily shallow-water relatives (Hall and Thatje 2009). This study, for the first time, examines the hypothesis of a lineage-wide physiological thermal threshold using a biogeographical dataset.

Temperature affects the most fundamental biological processes; in ectotherms, all aspects of life-from basic chemical reactions to feeding and reproductive behaviour - can be related to environmental temperature (Pörtner 2001). Physiological limitations within the Lithodidae mean that larvae will not successfully develop to maturity at temperatures lower than $0-2^{\circ} \mathrm{C}$ in laboratory experiments (Nakanishi 1981; Shirley and Shirley 1989; Thatje 2004). The speed of growth and development is reduced after even a small decrease in environmental temperature (Kurata 1960; Nakanishi 1985; Anger et al. 2003, 2004; Calcagno et al. 2003, 2005). This can be particularly important for early life stages that are vulnerable to seasonal fluctuations in food abundance and size-related predation pressures (Holm-Hansen 1985, Thatje 2004). Latitudinal clines in fecundity and egg size (Wägele 1987; Gorny et al. 1992; Fischer et al. 2009) are indications of the increased cost of reproduction at high latitudes and the transition to a reproductive strategy with increased energy investment per offspring (Atkinson et al. 2001; Thatje 2004). The adoption of a lecithotrophic larval mode of development in the deep-sea genera of the Lithodidae allows independence from seasonal primary production and enables tolerance of the protracted development times that are associated with cold waters in polar and deep-sea environments (Shirley 
and Zhou 1997; Thatje et al. 2003). Optimal levels of growth and survival during larval development occur between 5 and $10^{\circ} \mathrm{C}$ in laboratory-reared lithodid species (Anger et al. 2003; Jørgensen et al. 2005).

\section{The Southern Ocean}

Very few crushing seafloor predators inhabit the waters around Antarctica and even fewer on the continental shelf (Thatje and Arntz 2004; Aronson et al. 2007); brachyuran crabs, which are important community-structuring predators elsewhere in the shallow ocean, are absent from Southern Ocean (Gorny 1999; Frederich et al. 2001). The general lack of crabs, sharks and rays on the high-Antarctic continental shelves may be one of the primary explanations for the rather archaic structure and function of shelf benthos when compared with shallow-water communities elsewhere in the oceans (for review see Aronson et al. 2007). The presence of large anomuran crabs in the Southern Ocean is limited to the Lithodidae, which have been found in several deep-water locations including the continental slope of the West Antarctic Peninsula (Klages et al. 1995; Thatje and Arntz 2004; Ahyong and Dawson 2006; Thatje et al. 2008). Three genera of deep-sea lithodids (Lithodes, Neolithodes and Paralomis) are found at latitudes above $60^{\circ} \mathrm{S}$, although species number is lower than in the adjacent sub-Antarctic regions (Lovrich et al. 2005; Thatje et al. 2005). For several reasons, the Southern Ocean is an interesting study area for examining temperature-linked distributional trends in mobile, benthic organisms such as the Lithodidae, whose evolutionary history in the deep sea has been established (Hall and Thatje 2009).

- The region $\left(40-60^{\circ} \mathrm{S}\right)$ is divided by persistent oceanic fronts within the Antarctic Circumpolar Current (ACC), which extend to great depths and are identified by marked temperature changes (Deacon 1937; Nowlin and Klink 1986; Moore et al. 1999; Barker and Thomas 2004). The ACC is bounded to the north by the subtropical front $\left(35-45^{\circ} \mathrm{S}\right)$, where cold sub-Antarctic waters meet warm, saline subtropical waters (Orsi et al. 1995; Rintoul et al. 2001). To the south (c. $\left.60^{\circ} \mathrm{S}\right)$, the ACC is defined by the Antarctic Divergence, where there is an upwelling of deep waters (Fig. 1).

- The Southern Ocean includes some of the coldest waters on earth and spans the physiological lower temperature range for the Lithodidae. The Weddell Sea, for example, has temperatures consistently below $0.5^{\circ} \mathrm{C}$ (Lamb 1977; Barnes et al. 2006) and would not be expected to support reproductive lithodid populations based on experimental data (Shirley and Shirley 1989; Thatje 2004).

- Temperature regimes in the Southern Ocean are changing over time and space, with the changing position of the fronts and a steady increase in water temperature.

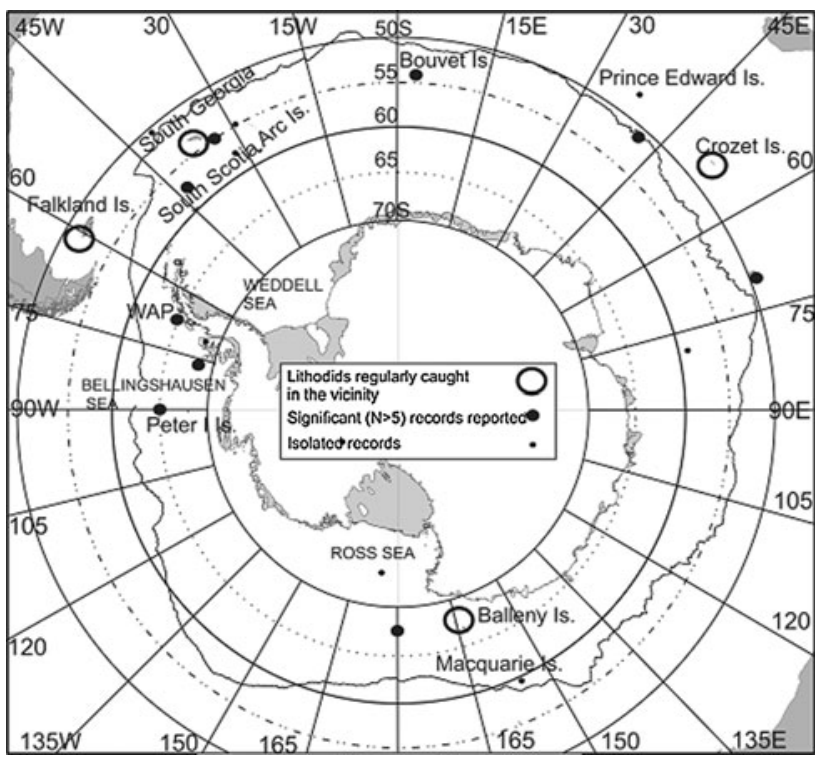

Fig. 1 Map of the Southern Ocean indicating the position of the Antarctic convergence: part of the circumpolar current. This study area is divided by the $60^{\circ} \mathrm{S}$ line of latitude into sub-Antarctic $\left(45-60^{\circ} \mathrm{S}\right)$ and Antarctic $\left(60^{\circ} \mathrm{S}+\right)$ regions. Dots indicate the major sites in which lithodids have been found to date. Refer to references for exact locations

Locations such as the West Antarctic Peninsula (WAP) are among the fastest warming areas on earth as a result of global warming (Meredith and King 2005).

This study aims to establish the baseline for a link between temperature and distribution of the family Lithodidae in a region with many potential thermal 'barriers'. This dataset will be expanded through further scientific discovery and will be instrumental in the future to illustrate and understand the changing faunal distributions in some of the most rapidly changing marine environments on earth (Meredith and King 2005; Aronson et al. 2007).

\section{Materials and methods}

The study area

For this study, the sub-Antarctic/Southern Ocean region (Fig. 1) was divided into two sections based on latitude and oceanographic features. The range $45-60^{\circ} \mathrm{S}$ includes locations within the ACC, from the sub-Antarctic front to the southern circum-Antarctic front (Antarctic divergence). The ACC itself passes south of Patagonia before diverging across the Argentine continental shelf (Antezana 1999), so fauna in and around coastal South America are not included in this study.

The range $60-75^{\circ} \mathrm{S}$ approximately includes all waters south of the Antarctic divergence (the southern boundary of 
the ACC). Scott Island in the Ross Sea, Peter I island in the Bellingshausen Sea, and the West Antarctic Peninsula (WAP) (all south of $60^{\circ} \mathrm{S}$ ) lie south of the Antarctic divergence. Discontinuities in lithodid distribution mean that $60^{\circ} \mathrm{S}$ is a convenient division of the region for the purpose of this study (Thatje et al. 2005; Ahyong and Dawson 2006; Thatje et al. 2008).

Data sources

Data were gathered from three sources, as follows:

(1) Published records of lithodids were sourced from peerreviewed journals and other literature (including some comprehensive reviews of faunal distributions in different regions of the Southern Ocean Acosta et al. 1989; Ahyong and Dawson 2006; Ahyong 2010; Arana and Retamal 1999; García Raso et al. 2005; Klages et al. 1995; López Abellán and Balguerías 1993; Macpherson 1988, 2004; Miquel et al. 1985; Purves et al. 2003; Spiridonov et al. 2006; Thatje et al. 2005, 2008) Identity was verified from descriptions and pictures, or by inspection where samples were deposited in museums.

(2) Specimens (mostly unpublished records) were examined from museum collections in the Natural History Museum, London (NHM); Senckenberg Museum, Frankfurt; Musée National d'Histoire Naturelle, Paris (MNHN); Institut de Ciencies del Mar, Barcelona; United States National Museum of Natural History, Smithsonian Institute, Washington (USNM).

(3) Specimens with associated environmental data were obtained courtesy of commercial vessels or scientific cruises; material from the 2007 R.V. James Clark Ross cruise to the Bellingshausen Sea (JCR166) and material from Atlantis ' 08 expedition were used.

For each specimen studied, the depth, location and date of sample collection were noted. The study included all of the 17 species of lithodid described to date from the study area. Data from 82 sample locations (indicated in Fig. 1) south of $45^{\circ} \mathrm{S}$ (not including South American continent) were used in this study. Water temperature at the time of sampling was obtained from cruise reports where possible. Otherwise, temperatures were estimated based on time of year, depth and location. The majority of the estimated environmental data were taken from the National Oceanographic Data Centre <World Ocean Atlas 2005> (Locarnini et al. 2006) and the <Southern Ocean Atlas $>$ (Olbers et al. 1992) (http://odv.awi.de/en/data/ocean/southern_ocean_atlas/).

Within each latitudinal range outlined above $\left(45-60^{\circ} \mathrm{S}\right.$, $\left.60-75^{\circ} \mathrm{S}\right)$, the longitudinal and depth distributions were examined within and between species of lithodids (Figs. 3, $5,6,7)$. The southern-most frontier of the lithodid distribution was examined by plotting water temperature variation with depth and longitude at $55^{\circ} \mathrm{S}, 60^{\circ} \mathrm{S}, 65^{\circ} \mathrm{S}, 70^{\circ} \mathrm{S}$ and $75^{\circ} \mathrm{S}$ (Figs. 3, 4, 5, 6, 7). These data were sampled from the $<$ Southern Ocean Atlas > (Olbers et al. 1992); each temperature estimate included all data from within two degrees of the stated latitude (e.g. $60 \pm 2^{\circ} \mathrm{S}$ ). Temperature at depths of $200,500,1,000$, and 2,000 $\mathrm{m}$ were sampled, because they are relevant to the distribution of lithodids in this region.

\section{Results}

Antarctic and Subantarctic distribution

Members of the lithodid genera Paralomis, Lithodes and Neolithodes inhabit some of the relatively warmer waters around Antarctica (Klages et al. 1995; Arana and Retamal 1999; García Raso et al. 2005; Thatje et al. 2008; Ahyong 2010). Most often, the ambient temperatures in which lithodids are found in Antarctic/sub-Antarctic waters are between 1 and $4^{\circ} \mathrm{C}$. The coldest waters in which lithodids have been found are between 0.4 and $0.5^{\circ} \mathrm{C}$ in the Ross Sea (Fig. 2).

\section{Region $45-60^{\circ} \mathrm{S}$}

Fourteen species of lithodids are known to occur between 45 and $60^{\circ} \mathrm{S}$ (Paralomis aculeata, P. anamerae, P. birsteini, $P$. elongata, $P$. formosa, $P$. granulosa, $P$. spinosissima, Lithodes confundens, L. murrayi, L. santolla, L. turkayi, Neolithodes diomedeae, N. duhameli, N. capensis). Paralomis spinosissima, $P$. formosa and $P$. anamerae have overlapping distributions, and numerous specimens have been found around South Georgia (Fig. 3). Exploratory fisheries

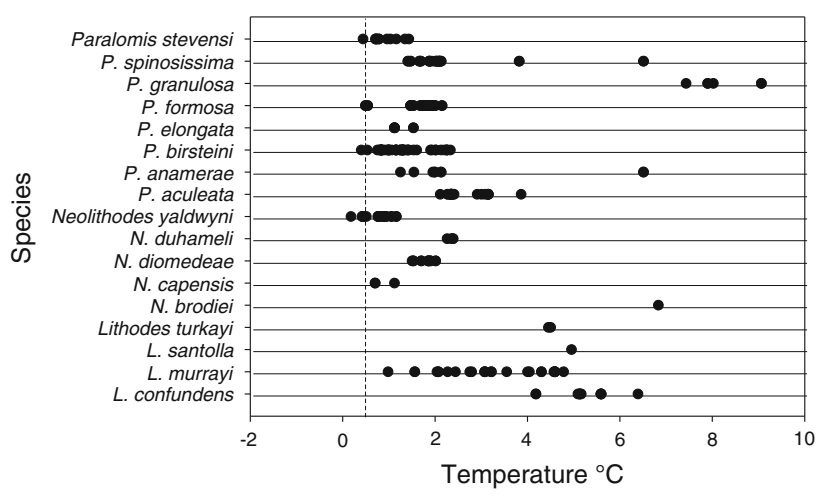

Fig. 2 Temperature measured or estimated at sample location for species of Lithodinae south of $45^{\circ} \mathrm{S}$ (excluding Patagonia). Temperature data obtained either from in situ measurements at the time of capture, or from the <Southern Ocean Atlas> (Olbers et al. 1992). A dashed line at $0.5^{\circ} \mathrm{C}$ indicates the predicted physiological threshold for some members of the family, coinciding with the coldest waters in which many lithodid species are known to persist 


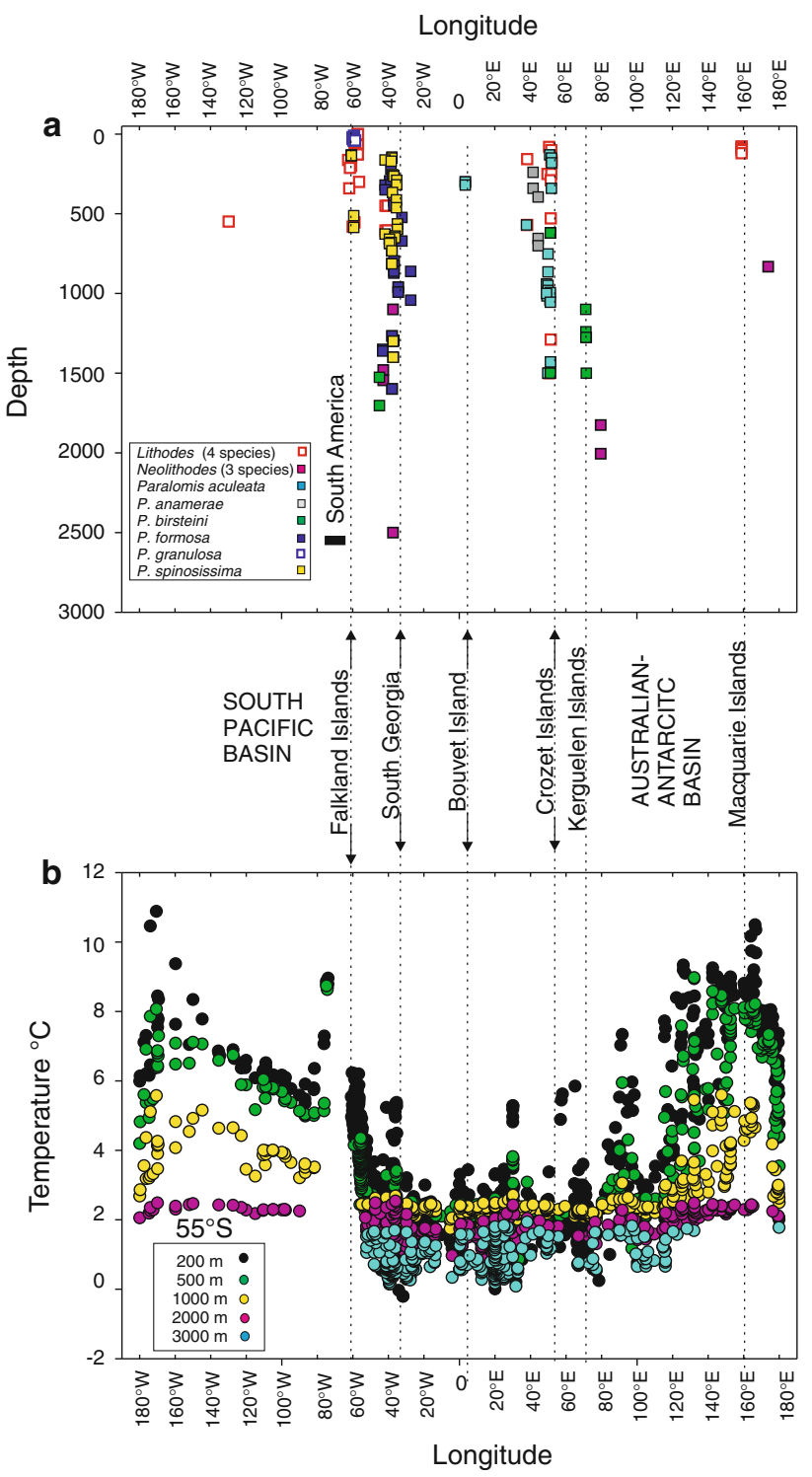

Fig. 3 a Lithodidae captured between 45 and $60^{\circ} \mathrm{S}$ shown by sampled depth against longitude. To increase graphical clarity, species Lithodes murrayi, L. santolla, $L$. confundens and $L$. turkayi are pooled; as are species Neolithodes diomedeae $\left(50-30^{\circ} \mathrm{W}\right), N$. duhameli $\left(60-80^{\circ} \mathrm{E}\right)$ and $N$. brodiei $\left(170^{\circ} \mathrm{E}\right)$. Paralomis elongata $\left(3^{\circ} \mathrm{E}\right)$ and P. aculeata $(30$ $60^{\circ} \mathrm{E}$ ) were shown to be synonymous in molecular studies (Thatje et al. 2008); b Temperatures at depths 200, 500, 1,000, 2,000 and 3,000 m below sea level at longitudes between 54 and $56^{\circ} \mathrm{S}$. Data obtained from the $<$ Southern Ocean Atlas $>$ (Olbers et al. 1992)

have shown that $P$. spinosissima is encountered regularly in waters between 200-800 m around Shag Rocks and South Georgia (López Abellán and Balguerías 1993; Purves et al. 2003). Paralomis formosa is found in deeper waters, typically $600-1,600 \mathrm{~m}$ (Purves et al. 2003; Thatje et al. 2005) and adults have been found where ambient temperatures are between 0.5 and $2.1^{\circ} \mathrm{C}$ (Figs. 2, 3). In the southern islands of the Scotia Arc $\left(60^{\circ} \mathrm{S}, 25-60^{\circ} \mathrm{W}: 0.5\right.$ to $-1^{\circ} \mathrm{C}$; Fig. 4$)$, no populations of Paralomis have been identified above
Longitude

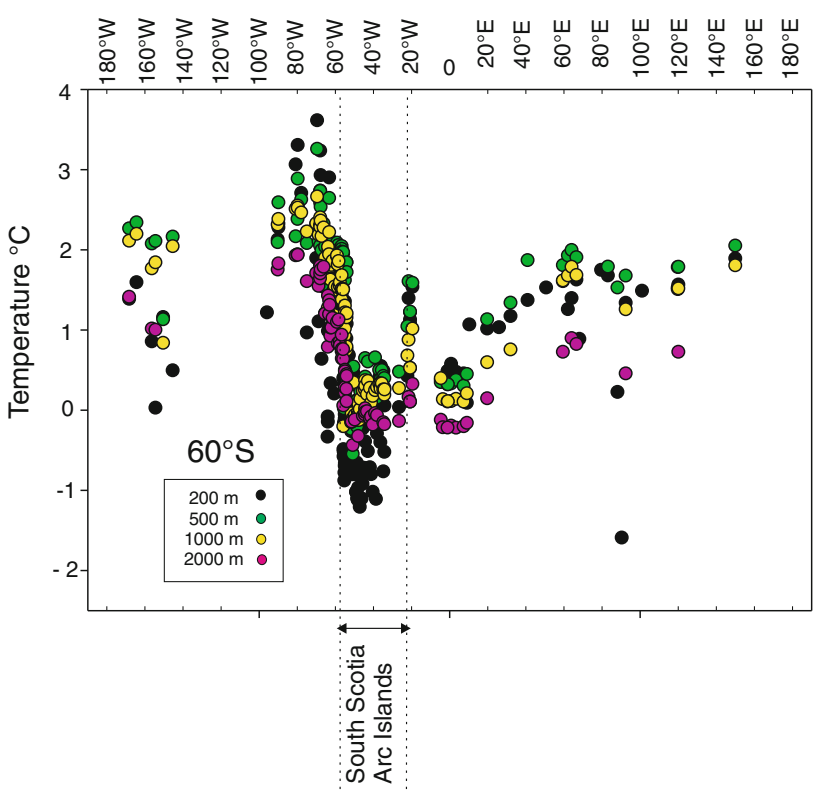

Fig. 4 Temperatures at depths 200, 500, 1,000 and 2,000 m below sea level at longitudes between 59 and $61^{\circ} \mathrm{S}$. Data obtained from the $<$ Southern Ocean Atlas> (Olbers et al. 1992). No lithodids are found between these latitudes despite a significant sampling effort around the southern islands of the Scotia Arc (indicated)

500 m, despite a significant sampling effort (López Abellán and Balguerías 1993). Paralomis aculeata was originally described at $600 \mathrm{~m}$ off the Prince Edward Islands $\left(45^{\circ} \mathrm{S}\right)$ and is known also from the Crozet Islands in the southern Indian Ocean $\left(46^{\circ} \mathrm{S}\right.$ : Arnaud and Do-Chi 1979; Miquel et al. 1985; Macpherson 2004). It has a wide bathymetric range, approximately $150-1,500 \mathrm{~m}$, and a recorded temperature range from 2 to $4^{\circ} \mathrm{C}$ (Fig. 2). Between $25^{\circ} \mathrm{W}$ and $30^{\circ} \mathrm{E}$, no records of any lithodids exist to date, with the exception of $P$. elongata at $300 \mathrm{~m}$ close to Bouvet Island $\left(54^{\circ} \mathrm{S}, 2^{\circ} \mathrm{E}\right.$; $0.5-3^{\circ} \mathrm{C}$, Fig. 3; Arntz et al. 2006; Spiridonov et al. 2006). This gap in distribution coincides with low water temperatures in the mid-Atlantic $\left(1.5-0^{\circ} \mathrm{C}\right.$ at $55^{\circ} \mathrm{S}$ : Fig. 3), although the sampling effort in this region is unknown.

\section{Region $60+{ }^{\circ} \mathrm{S}$}

Within high-Antarctic waters above $60^{\circ} \mathrm{S}$, lithodid diversity declines substantially and includes species Paralomis birsteini, P. stevensi, Lithodes murrayi, Neolithodes diomedae, N. yaldwyni and N. capensis (Figs. 5, 6, 7). At $65^{\circ} \mathrm{S}$, temperature dips substantially below zero in the Weddell Sea and in the Australian-Antarctic basin, particularly above $500 \mathrm{~m}$ (Fig. 5). The areas between $60-70^{\circ} \mathrm{S}$ in which lithodids are found are those with notably higher temperatures $\left(0.5-2.5^{\circ} \mathrm{C}\right.$, Figs. 5, 6, 7), such as the Bellingshausen 
Longitude

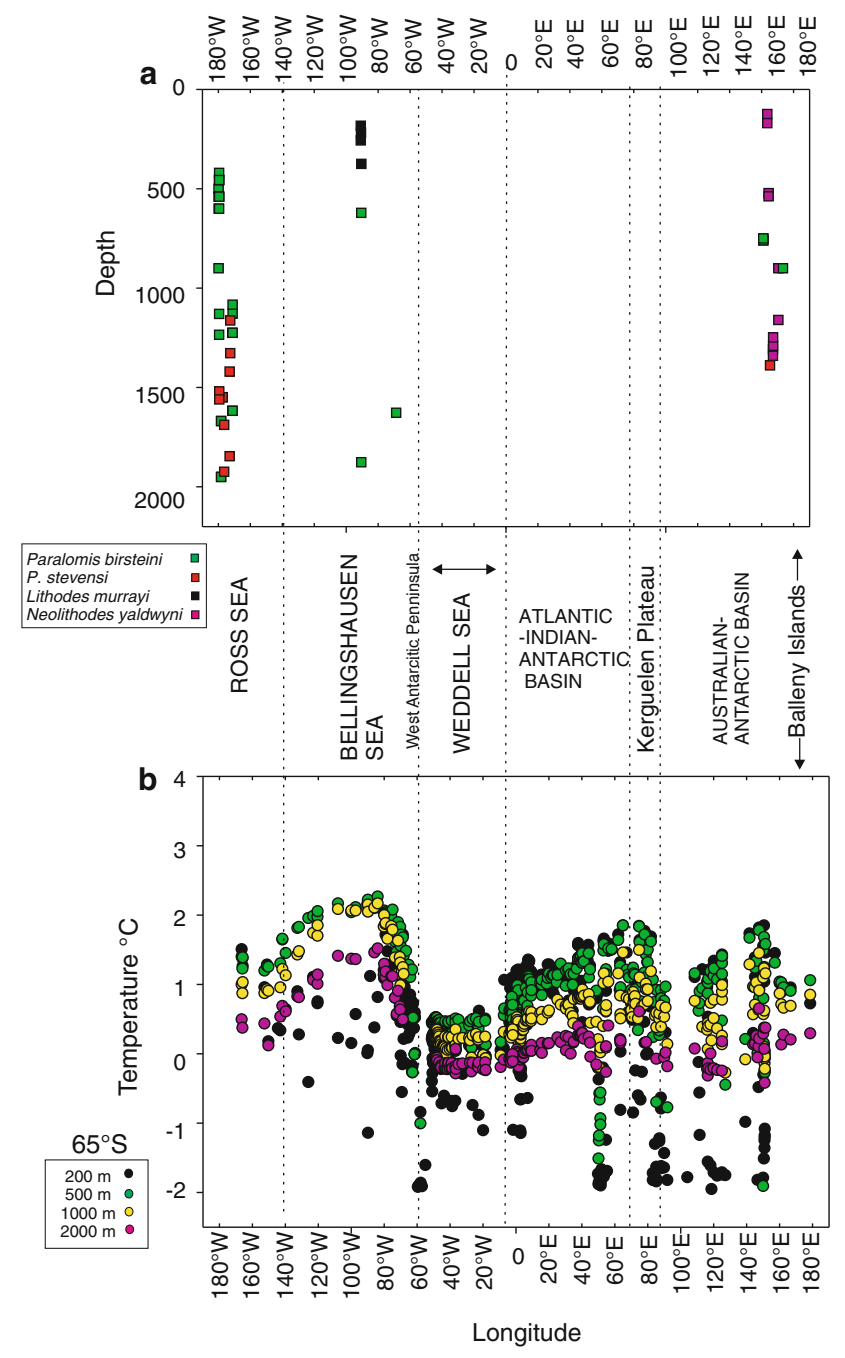

Fig. 5 a Sample depth and longitude of Lithodidae captured between of 62.5 and $67.5^{\circ} \mathrm{S}$. b Temperatures at depths 200, 500, 1,000 and $2,000 \mathrm{~m}$ below sea level at longitudes between 64 and $66^{\circ} \mathrm{S}$. Data obtained from the <Southern Ocean Atlas $>$ (Olbers et al. 1992)

Sea and the Balleny islands near the Ross Sea. Lithodids are present on the continental slope of the West Antarctic Penninsula (WAP) but have not yet been found on the continental shelf, where temperatures are around $1^{\circ} \mathrm{C}\left(60^{\circ} \mathrm{W}\right.$, Fig. 5). The Southern Ocean below $70^{\circ} \mathrm{S}$ is divided by the continental landmass into a Weddell Sea section ( -2 to $\left.1^{\circ} \mathrm{C}\right)$ and a Ross Sea section $\left(0.5-1.5^{\circ} \mathrm{C}\right)$. To date, lithodids have only rarely been found south of $70^{\circ} \mathrm{S}$ and they are absent at all latitudes from the Weddell Sea. Sparse records of adult Neolithodes yaldwyni from more than 1,000 m water depth at $75^{\circ} \mathrm{S}$ in the Ross Sea sector are taken from waters where the temperature is around $1^{\circ} \mathrm{C}$ (Fig. 7). The continental shelf above $75^{\circ} \mathrm{S}$ in both the Weddell Sea and the Ross Sea is colder than $0.5^{\circ} \mathrm{C}$, reaching sub-zero temperatures (Fig. 7).

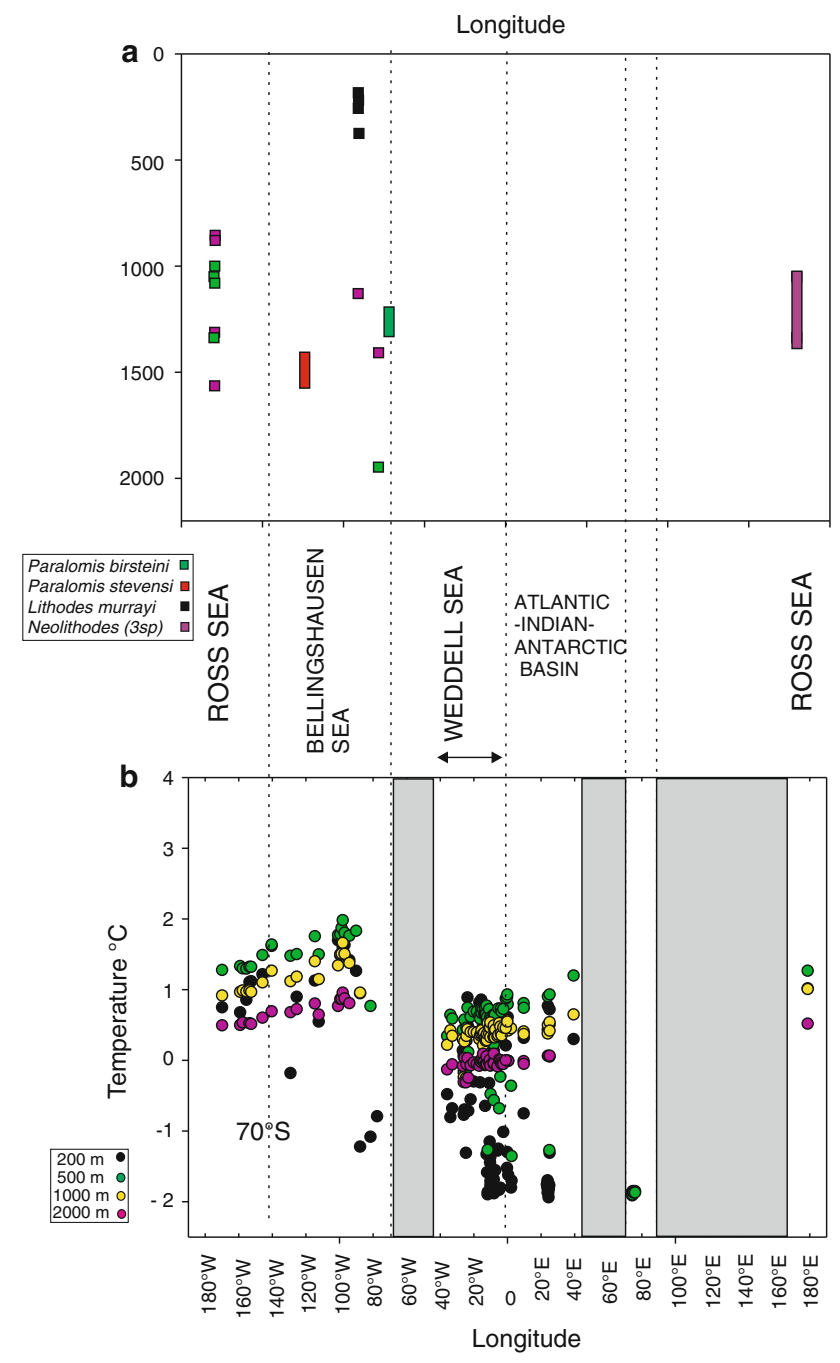

Fig. 6 a Sample depth and longitude of Lithodidae captured between of 67.5 and $72.5^{\circ} \mathrm{S}$ (none recorded in this range above $70^{\circ} \mathrm{S}$ ). Neolithodes species are $N$. yaldwyni, $N$. capensis and $N$. diomedeae. b Temperatures at depths 200,500, 1,000 and 2,000 m below sea level at longitudes between 69 and $71^{\circ} \mathrm{S}$. Data obtained from the $<$ Southern Ocean Atlas $>$ (Olbers et al. 1992). Grey blocks represent landmass above sea-level

\section{Discussion}

Temperatures in the Southern Ocean are low but stable; seasonal temperatures only fluctuate by a few degrees Celsius (Foster 1984). Diversity of lithodids in the region $45-60^{\circ} \mathrm{S}$ is higher than $60-70^{\circ} \mathrm{S}$, and species Neolithodes yaldwyni and Paralomis stevensi are both endemic to waters south of $60^{\circ} \mathrm{S}$. This indicates that some adaptations to very low temperatures are present in lithodids living at the lowest end of the family's temperature range (Hall and Thatje 2009).

A limit to the currently recognised range of the Lithodidae coincides with regions where water temperature is colder 

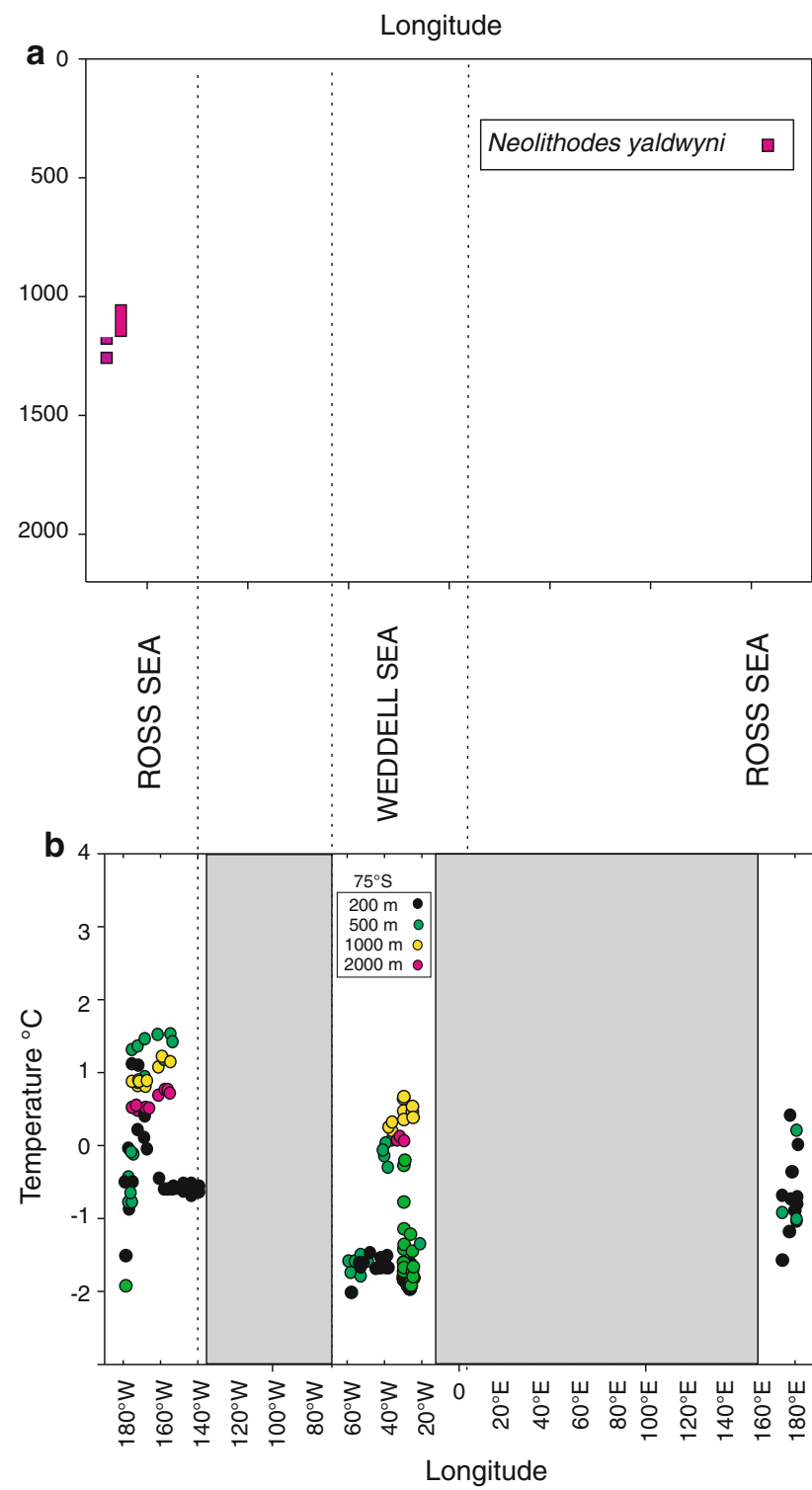

Fig. 7 a Sample depth and longitude of Lithodidae captured between of 72.5 and $76^{\circ} \mathrm{S}$. b Temperatures at depths 200,500 and $1,000 \mathrm{~m}$ below sea level at longitudes between 73 and $76^{\circ} \mathrm{S}$. Data obtained from the <Southern Ocean Atlas> (Olbers et al. 1992). Grey blocks represent landmass above sea-level

than $0.4^{\circ} \mathrm{C}$ (Fig. 2), such as the Weddell Sea (Figs. 5, 6, 7) and the Antarctic continental shelf at all longitudes (Figs. 6, 7). Close to the Antarctic continent, particularly in the Weddell and Ross Seas, extremely dense, cold Antarctic Bottom water $(\mathrm{AABW})$ sinks from the surface to the deep sea. The Scotia Arc, between the Antarctic Peninsula and Patagonia (Acosta et al. 1989), has northern (South Georgia, c. 52 ${ }^{\circ} \mathrm{S}$ ) and southern archipelagoes (South Shetland, South Orkney, c. $59^{\circ} \mathrm{S}$ ), which have different temperature profiles and faunal distributions (e.g. Lovrich et al. 2005; Griffiths et al. 2008). The cold deep water formed in the Weddell Sea makes the temperature in the south-east Scotia Ridge particularly low (Fig. 4). This is a possible reason for the absence of the Lithodidae from this area, despite their abundance in the archipelago to the north (Gorny 1999; Arntz et al. 2005).

Temperatures are greater than $0.5^{\circ} \mathrm{C}$ in some areas from which lithodids are thought to be excluded, such as $70^{\circ} \mathrm{S}$ in the Ross Sea (Fig. 6b) and the continental shelf of the WAP. On the WAP continental shelf, for example, temperatures are only slightly lower $\left(1-1.5^{\circ} \mathrm{C}\right.$, Fig. 5$)$ than the adjacent continental slope, where lithodids are present (Thatje et al. 2008). Sampling effort is significant in the Southern Ocean, especially in the Weddell Sea and shallower parts of the WAP region (e.g. Arntz et al. 2005, Brandt et al. 2007), but it can not be ascertained to what extent the lack of records is the result of undersampling.

Physiological experiments to date have suggested a lower limit for larval development between 1 and $0.5^{\circ} \mathrm{C}$ in some Southern Ocean species (Thatje 2004 and references therein). Adult specimens found in the very coldest waters of the Southern Ocean might be migrant rather than reproductive populations-adults may tolerate temperatures lower than do larvae or juveniles, meaning that reproductive populations can't establish at the frontier of the lithodid range. Contrary to this hypothesis, thirteen specimens of P. birsteini, including juveniles, were recently videorecorded between 1,123 and $1,394 \mathrm{~m}$ water depths on the Antarctic continental slope/rise in the Bellingshausen Sea (Thatje et al. 2008; see also García Raso et al. 2005). This, as well as the presence of ovigerous females of $P$. stevensi and P. birsteini (Ross Sea: Ahyong and Dawson 2006; Bellingshausen Sea: Arana and Retamal 1999) above $60^{\circ} \mathrm{S}$, indicates that reproductively active populations of at least some lithodid species do, in fact, exist south of the Antarctic divergence. No records of lithodid larvae have been found within the Southern Ocean; however, deep-sea lithodids are understood to have lecithotrophic larvae that disperse by drifting close to the sea floor (Thatje 2004; Lovrich 1999).

The changing thermal structure of oceans may play an important role in determining patterns of lithodid biogeography. This could be an increasingly important phenomenon in consideration of climate change and oscillations in oceanic upwelling zones (Thatje et al. 2005). Warming of the polar oceans might be gradually opening up new habitats to the Southern Ocean lithodids (Aronson et al. 2007), and the slight mismatch between distributional and physiologically theoretical thresholds could be evidence of a range-expansion in progress.

Species of the genera Paralomis, Lithodes and Neolithodes are among the few anomuran taxa found at high latitudes in the Southern Ocean and it seems likely that a history of deep-sea adaptation (Thiel et al. 1996; Thatje 2004), has been associated with their successful colonization of Polar regions. In the Antarctic, particularly in the Bellingshausen Sea, lithodids have the potential to threaten 
the isolated shelf communities (Thatje et al. 2005; Aronson et al. 2007), which have evolved in the absence of crushing predators (such as crabs, lobsters, sharks and rays) that would be found in shelf ecosystems at lower latitudes (Feldmann and Tshudy 1989; Dayton et al. 1974; Arntz et al. 1994; Crame 1994; McClintock and Baker 1997). Here, where lithodids of the subfamily Lithodinae seem to be living at the lower boundary of their physiological threshold, even a slight increase in temperature might open up new habitats. Lithodids have the potential to expand into previously uninhabitable regions of polar seas if water temperatures continue to increase, with potentially devastating effects for the Antarctic shelf fauna.

Acknowledgments This research is supported through a grant from the Total Foundation (Abyss2100) to Sven Thatje. We would like to thank staff at the National Museum of Natural History, Smithsonian Institute, Washington (USNM), especially Rafael Lemaitre and Karen Reed; Régis Cleva at the Muséum national d'Histoire naturelle, Paris (MNHN); Paul Clark at the Natural History Museum (NHM), London; Enrique Macpherson at the Centro de Estudios Avanzados de Blanes; Michael Türkay at the Senckenberg Museum, Frankfurt; and Ana Ramos and her group at Instituto Español de Oceanografía, Vigo. This study would not have been possible without the information made available by these institutions. This work was supported by the Marine Biodiversity and Ecosystem Functioning Network of Excellence MarBEF (contract no. GOCE-CT-2003-505446) of the FP6, and through a NERC PhD studentship to Sally Hall.

\section{References}

Acosta J, Canals M, Herranaz P, Sans JL (1989) Investigación geológica-geofísica y sedimentológica en el arco de Escócia y península Antártica. In: MAPA (ed) Resultados de la campagna “ANTARTIDA 8611". Publ Espec Inst Esp Oceanogr No 2, Madrid, pp 9-82

Ahyong ST (2010) King crabs of New Zealand, Australia and the Ross Sea (Crustacea: Decapoda: Lithodidae. NIWA Biodiv Mem 123:1-194

Ahyong ST, Dawson EW (2006) Lithodidae from the Ross Sea, Antarctica, with descriptions of two new species (Crustacea: Decapoda: Anomura). Zootaxa 1303:45-68

Anger K, Thatje S, Lovrich G, Calcagno J (2003) Larval and early juvenile development of Paralomis granulosa reared at different temperatures: tolerance of cold and food limitation in a lithodid crab from high latitudes. Mar Ecol Prog Ser 253:243-251

Anger K, Lovrich GA, Thatje S, Calcagno JA (2004) Larval and early juvenile development of Lithodes santolla (Molina, 1782) (Decapoda: Anomura: Lithodidae) reared at different temperatures in the laboratory. J Exp Mar Biol Ecol 306:217-230

Antezana T (1999) Plankton of the southern Chilean fjords: trends and linkages. Scient Mar 63(supp 1):69-80

Arana EP, Retamal MA (1999) New distribution of Paralomis birsteini Macpherson, 1988 in Antarctic waters (Anomura, Lithodidae, Lithodinae). Invest Mar (Valparaíso) 27:101-110

Arnaud PM, Do-Chi T (1979) Résultats préliminaries obtenus sur les lithodes aux iles Crozet, Marion et Prince Edward, pendant la campagne océanographique MD.08. C.N.F.R.A. (Comité nat franç Rech antarct) 44:135-136

Arntz W, Brey T, Gallardo VA (1994) Antarctic zoobenthos. Oceanogr Mar Biol Ann Rev 32:241-304
Arntz WE, Thatje S, Gerdes D, Gili JM, Gutt Jacob U, Montiel A, Orejas C, Teixidó N (2005) The Antarctic-Magellan connection: Macrobenthos ecology on the shelf and upper slope, a progress report. Scient Mar 69(Suppl 2):237-269

Arntz WE, Thatje S, Linse K, Avila C, Ballesteros M, Barnes DKA, Cope T, Cristóbo Rodríguez FJ, De Broyer C, Gutt J, Isla E, López-González P, Montiel A, Munilla T, Ramos Esplá AA, Raupach M, Rauschert M, Rodríguez E, Teixidó T (2006) Missing link in the Southern Ocean: sampling the marine benthic fauna of remote Bouvet Island. Polar Biol 29:83-96

Aronson RB, Thatje S, Clarke A, Peck LS, Blake DB, Wilga CD, Seibel BA (2007) Climate change and invasibility of the Antarctic benthos. Annu Rev Ecol Evol System 38:129-154

Atkinson D, Morley SA, Weetman D, Hughes RN (2001) Offspring size responses to maternal temperature in ectotherms. In: Atkinson D, Thorndyke $M$ (eds) Environment and animal development: Genes, Life histories and plasticity. Oxford Bios Scientific Publishers, Oxford, pp 265-285

Barker PF, Thomas E (2004) Origin, signature and palaeoclimatic influence of the Antarctic circumpolar current. Earth Sci Rev 66(1-2):143-162

Barnes DA, Fuentes V, Clarke A, Schloss IR, Wallace MI (2006) Spatial and temporal variation in shallow seawater temperatures around Antarctica. Deep-Sea Res II 53(8-10):853-865

Brandt A, Gooday AJ, Brandao SN, Brix S, Brokeland W, Cedhagen T, Choudhury M, Cornelius N, Danis B, De Mesel I, Diaz RJ, Gillan DC, Ebbe B, Howe JA, Janussen D, Kaiser S, Linse K, Malyutina M, Pawlowski J, Raupach M, Vanreusel A (2007) First insight into the biodiversity and biogeography of the Southern Ocean deep sea. Nature 447:307-312

Calcagno JA, Thatje S, Anger K, Lovrich GA, Kaffenberger A (2003) Changes in biomass and chemical composition during lecithotrophic larval development of the Southern stone crab, Paralomis granulosa (Jacquinot). Mar Ecol Prog Ser 257:189-196

Calcagno JA, Lovrich GA, Thatje S, Nettelmann U, Anger K (2005) First year growth in the lithodids Lithodes santolla and Paralomis granulosa reared at different temperatures. J Sea Res 54(3):221-230

Crame JA (1994) The evolutionary history of Antarctica. In: Hempel G (ed) Antarctic science-global concerns. Springer, Berlin, pp 188-214

Dayton PK, Robillard GA, Paine RT, Dayton LB (1974) Biological accommodation in the benthic community at McMurdo Sound, Antarctica. Ecol Monogr 44:105-128

Deacon GER (1937) The hydrology of the Southern Ocean. Discov Rep 15:3-122

Feldmann RM, Tshudy DM (1989) Evolutionary patterns in macrurous decapod crustaceans from Cretaceous to early Cenozoic rocks of the James Ross Island region, Antarctica. In: Crame JA (ed) Origins of the Antarctic Biota. Geological Society, Special Publications, London, pp 183-195

Fischer S, Thatje S, Brey T (2009) Early egg traits in Cancer setosus (Decapoda Brachyura): effects of temperature and female size. Mar Ecol Prog Ser 377:193-202

Foster TD (1984) The marine environment. In: Laws RM (ed) Antarctic ecology, vol 2. Academic Press, London, pp 345-371

Frederich M, Sartoris FJ, Pörtner HO (2001) Distribution patterns of decapod crustaceans in polar areas: a result of magnesium regulation? Polar Biol 24:719-723

García Raso JE, Manjón-Cabeza ME, Ramos A, Olasi I (2005) New record of Lithodidae (Crustacea, Decapoda, Anomura) from the Antarctic (Bellingshausen Sea). Polar Biol 28:642-646

Gorny M (1999) On the biogeography and ecology of the Southern Ocean decapod fauna. Scient Mar 63(S1):367-382

Gorny M, Arntz WE, Clarke A, Gore DJ (1992) Reproductive biology of caridean decapods from the Weddell Sea. Polar Biol 12:111-120 
Griffiths HJ, Linse K, Barnes DKA (2008) Distribution of macrobenthic taxa across the Scotia Arc, Antarctica. Antarct Sci 20(3):213-226

Hall S, Thatje S (2009) Global bottlenecks in the distribution of marine Crustacea: temperature constraints in the family Lithodidae. J Biogeogr 36(11):2125-2135

Holm-Hansen O (1985) Nutrient cycles in Antarctic marine ecosystems. In: Siegfried WR, Condy RR, Laws RM (eds) Antarctic nutrient cycles and food webs. Springer, Berlin, pp 6-10

Jørgensen LL, Manushin I, Sundet JH, Birkely SR (2005) The intentional introduction of the marine red king crab Paralithodes camtschaticus into the southern Barents Sea. ICES Cooper Res Rep vol 277, p 18

Klages M, Gutt J, Starmans A, Bruns T (1995) Stone crabs close to the Antarctic continent: Lithodes murrayi Henderson, 1888 (Crustacea; Decapoda; Anomura) off Peter I Island (68 $\left.51^{\prime} \mathrm{S}, 91^{\circ} 51^{\prime} \mathrm{W}\right)$. Polar Biol 15:73-75

Kurata H (1960) Studies on the larva and post-larva of Paralithodes camtschatica III. The influence of temperature and salinity on the survival and growth of the larva. Bull Hokkaido Reg Fish Res Lab 21:9-14

Lamb HH (1977) Climatic history and the future. Methuen, London

Locarnini RA, Mishonov AV, Antonov JI, Boyer TP, Garcia HE (2006) World Ocean Atlas 2005 Volume 1: Temperature. NOAA Atlas NESDIS 61 (S. Levitus [ed]). US Government Printing Office, Washington, DC

López Abellán LJ, Balguerías JA (1993) On the presence of Paralomis spinosissima and $P$. formosa in catches taken during the Spanish survey Antartida 8611. CCAMLR Sci 1:165-173

Lovrich GA (1999) Seasonality of larvae of Brachyura and Anomura (Crustacea, Decapoda) in the Beagle Channel, Argentina. Scient Mar 63(Suppl 1):347-354

Lovrich GA, Romero MC, Tapella F, Thatje S (2005) Distribution, reproductive and energetic conditions of decapod crustaceans along the Scotia Arc (Southern Ocean). Scient Mar 69:183-193

Macpherson E (1988) Revision of the Family Lithodidae Samouelle, 1819 (Crustacea: Decapoda: Anomura) in the Atlantic Ocean. Monogr Zool Mar 2:9-153

Macpherson E (2004) A new species and new records of lithodid crabs (Crustacea: Decapoda: Lithodidae) from the Crozet and Kerguelen Islands area (Subantarctica). Polar Biol 27(7):418-422

McClintock JB, Baker BJ (1997) A review of the chemical ecology of Antarctic marine invertebrates. Am Zool 37:329-342

Meredith MP, King JC (2005) Rapid climate change in the ocean west of the Antarctic Peninsula during the second half of the 20th century. Geophys Res Lett 32:L19604

Miquel JC, Arnaud PM, Dochi T (1985) Population structure and migration of the stone crab Lithodes murrayi in the Crozet Islands, sub-Antarctic Indian Ocean. Mar Biol 89(3):263-269

Moore JK, Abbott MR, Richman JG (1999) Location and dynamics of the Antarctic Polar front from satellite sea-surface temperature data. J Geophys Res 104:3059-3073

Nakanishi T (1981) The effect of temperature on growth, survival and oxygen consumption of larvae and post larvae of Paralithodes brevipes. Bull Jpn Sea Reg Fish Res Lab (Nissuiken Hokoku) 32:49-56

Nakanishi T (1985) The effects of the environment on the survival rate, growth and respiration of eggs, larvae and post larvae of king crab (Paralithodes camtschatica). International King Crab Symposium. Alaska Sea Grant Ankorage, Alaska, pp 167-185
Nowlin WD, Klink JM (1986) The physics of the Antarctic circumpolar current. Rev Geophys 24:489-491

Olbers D, Gouretski VV, Seiss G, Schröter J (1992) The Hydrographic Atlas of the Southern Ocean. Alfred Wegener Institute for Polar and Marine Research, Bremerhaven, 17:82 plates. (http://odv. awi.de/en/data/ocean/southern_ocean_atlas/)

Orsi AH, Whitworth TW, Nowlin WD (1995) On the meridional extent and fronts of the Antarctic circumpolar current. Deep-Sea Res 42:641-673

Pörtner HO (2001) Climate change and temperature dependent biogeography: oxygen limitation of thermal tolerance in animals. Naturwissenschaften 88:137-146

Purves MG, Agnew DJ, Moreno G, Daw T, Yau C, Pilling G (2003) Distribution, demography, and discard mortality of crabs caught as bycatch in an experimental pot fishery for toothfish Dissostichus eleginoides in the South Atlantic. Fish Bull 101: 874-888

Rintoul SR, Hughes CW, Olbers D (2001) The Antarctic circumpolar current system. In: Siedler G, Church J, Gould J (eds) Ocean circulation and climate. Academic Press, London, pp 271-302

Shirley TC, Shirley SM (1989) Temperature and salinity tolerances and preferences of red king crab larvae. Mar Beh Physiol 16:19-30

Shirley TC, Zhou S (1997) Lecithotrophic development of the golden king crab Lithodes aequispinus (Anomura: Lithodidae). J Crust Biol 17(2):207-216

Spiridonov V, Türkay M, Arntz W, Thatje S (2006) A new species of the genus Paralomis from the Spiess seamount near Bouvet Island (Southern Ocean), with notes on habitat and ecology. Polar Biol 29:137-146

Thatje S (2004) Reproductive trade-offs in benthic decapod crustaceans of high southern latitudes: tolerance of cold and food limitation. Rep Polar Mar Res 483:1-183

Thatje S, Arntz WE (2004) Antarctic reptant decapods: more than a myth? Polar Biol 27:195-201

Thatje S, Schnack-Schiel S, Arntz WE (2003) Developmental tradeoffs in Subantarctic meroplankton communities and the enigma of low decapod diversity in high southern latitudes. Mar Ecol Prog Ser 260:195-207

Thatje S, Anger K, Calcagno JA, Lovrich GA, Pörtner HO, Arntz WE (2005) Challenging the cold: crabs reconquer the Antarctic. Ecology 86(3):619-625

Thatje S, Hall S, Held C, Hauton C, Tyler P (2008) Encounter of Paralomis birsteini on the continental slope of Antarctica, sampled by ROV. Polar Biol 31(9):1143-1148

Thiel H, Pörtner HO, Arntz WE (1996) Deep-sea and extreme shallowwater habitats: affinities and adaptations. In: Uiblein F, Ott $\mathrm{J}$, Stachowitsch M (eds) Deep-sea and extreme shallow-water habitats: affinities and adaptations. Biosystem Ecol Ser 11:183-219

Wägele J-W (1987) On the reproductive biology of Ceratoserolis trilobitoides (Crustacea: Isopoda): latitudinal variation of fecundity and embryonic development. Polar Biol 7:11-24

Zaklan SD (2002) Review of the family Lithodidae (Crustacea: Anomura: Paguroidea): Distribution, biology, and fisheries. In: Paul AJ, Dawe EG, Elner R, Jamieson GS, Kruse GH, Otto RS, SainteMarie B, Shirley TC, Woodby D (eds) Crabs in cold water regions: biology, management, and economics. University of Alaska Sea Grant College Program AK-SG-02-01, Fairbanks, pp 751-845 